\title{
PATENTS AND UNIVERSITY RESEARCH
}

\author{
Archire M. Palmer*
}

Research is conducted on the university campus as an integral part of the educational program, with a view to expanding the frontiers of human knowledge, encouraging and stimulating the spirit of inquiry, and contributing toward the training of scientific personnel. It is concerned with the discovery and dissemination of new ideas, so essential to scientific and technological progress. Some of these new ideas have valuable commercial application; others should be controlled in the public interest. In the handling of such results of university research the question of patents is involved.

The patent law ${ }^{1}$ provides that any new and useful art, ${ }^{2}$ machine, manufacture, or composition of matter, any new and useful improvement thereof, or any distinct and new variety of plant (other than a tuber-propagated plant) which has been asexually reproduced is subject to patent. Under this provision of the law many of the products of university research can be patented.

However, scientists working in university laboratories are, in general, content to pursue their investigations without thought of the practical application of the results. The discovery and development of patentable inventions are not primary objectives of their research efforts. They feel with Sir Henry Dale that "the primary and special function of research in the universities is to build the main fabric of knowledge by free and untrammelled inquiry and to be concerned with the practical uses of it, only as these arise in the course of a natural development."

\section{I}

The attitude is taken by many scientists, especially those working in universities, that the publication of the results of scientific research or the dedication of their findings to the public is sufficient. However, as President Karl T. Compton of the Massachusetts Institute of Technology said in his annual report for 1932, "Responsibility does not always end with mere publication of a patentable scientific discovery or invention; the public benefits derivable from the patent laws and contemplated by the framers of those laws should not be lost through a failure to solicit patent protection."

* A.B. 1920, Cornell University; M.A. 1927, Columbia University; D.C.L. 1941, University of the South. Director of Patent Policy Survey, National Research Council, since August, 1946. Author of Universtry Patent Policies (x934) and various works on university administration. Contributor to scientific and professional periodicals.

${ }^{1}$ Riev. STAT. $\$ 4886$ (I875), as amended, 35 U. S. C. $\$ 35$ (1940).

z Interpreted by the courts to include "method" or "process."

'Dale, Academic and Industrial Research in the Field of Therapeutics, 77 Sctence 525 (June 1933).

- Technology Review, Dec. r932, p. ror, col. 2. 
Discoveries or inventions that are merely published, and are thus made available to everybody equally, are seldom adopted, despite their possibilities of commercial application. As Elihu Thomson so aptly put it:

Publish an invention freely, and it will almost surely die from lack of interest in its development. It will not be developed and the world will not be benefited. Patent it, and if valuable, it will be taken up and developed into a business. ${ }^{5}$

Yet, some well-meaning scientists look askance at the patenting of the results of their investigations as if it were a rather selfish and ungracious act, essentially unworthy and unethical.

Writing in Chemical and Metallurgical Engineering in I921, William J. Hale defended the patenting of the results of university research work:

There is nothing dishonorable in a university scientist seeking a patent. On the contrary, he gains enormously thereby in international prestige. Of course, he usually is condemned at home by the university drones unable to comprehend the value of ideas other than their own; but such childish criticisms are negligible. No true scientist doubts for a moment the rights of a man to patent his own inventions. The great majority of our well-known chemists of England, France, and Germany are holders of patents in their respective countries. ${ }^{6}$

The patenting of the product of creative or inventive research need not necessarily bring direct personal profit to the research worker himself, even though the patent proves to be commercially profitable, nor need it distract his interest from fundamental research through the lure of greater rewards from work with patentable possibilities.

Financial rewards are not the essential or necessary objectives in obtaining patents. Of even greater importance are the protection of the public against exploitation by irresponsible or selfish persons, the regulation and control of the purity or reliability of the manufactured product (particularly in the case of a medical discovery), facility in licensing responsible concerns which can effectively commercialize the invention and invest sufficient capital to manufacture a product of appropriate quality without fear of unfair competition and piracy, the introduction of the invention to the public through proper channels and under the proper controls, and the provision through patent protection for unhampered further development-all in the public interest.

In discussing whether university patents are ethical, Yandell Henderson of Yale University has said:

Inventions, like all other new ideas, have generally to be forced on conservative mankind. It would be easy to point to many inventions and other applications of discovery now saving large numbers of lives that would not yet be in use without advertising and the efforts of salesmen. Without commercialization a large part of all the scientific ideas that are now in constant and active use in our daily lives would be locked in books on the

'Thomson, Address before Graduating Class, Massachusetts Institute of Technology, 75 ElECTRICAr WORID 1505 (1920).

'Hale, University Researchers Should Patent Discoveries in Their Own Names, 25 Chesncal aND Metallurgicat. Engineering 913-9r4 (1921). 
dusty shelves of university libraries. It is properly the business of the creative scholar to see to it that, if possible, his ideas serve mankind in his own generation.

But an even stronger duty rests on a discoverer or inventor. He should see to it that his idea or invention is not misused. He should control it. He should find one or more high-grade concerns to develop it. He should afford them at least such little protection as a patent gives against cut-throat competition, after they have spent money to put the invention into practical form and have made a market for it. Without some assurance of such protection it is difficult to get an idea developed and commercialized. The inventor should so far as possible prevent the sale of inferior or harmful imitations.7

A practicing physician, Elmer L. Sevringhaus, sums up the advantages which can be obtained from patenting in an article entitled Should Scientific Discoveries Be Patented?, written in 1932 when he was on the staff of the University of Wisconsin:

The public is thereby protected against certain ruinous types of exploitation. Assurance can be gained that technical processes are used in dependable ways. Even the publicity may be kept on a satisfactorily high plane. Rapid development of discoveries which are of academic interest may be secured when patent rights assure a commercial producer of protection in the field. ${ }^{8}$

In a report on The Protection by Patents of Scientific Discoveries, published in January, I934, the Committee on Patents, Copyrights, and Trademarks of the American Association for the Advancement of Science cited as some of the more pronounced objections frequently voiced against patenting the results of university research:

I. That it is unethical for scientists or professors to patent the results of their work;

2. That patenting will involve scientists in commercial pursuits and leave them little time for research;

3. That publication or dedication to the public is sufficient to give the public the results of the work of scientists;

4. That patenting leads to secrecy;

5. That a patent policy will lead to debasement of research;

6. That patents will place unfortunate strictures on other men who subsequently do fundamentally important work in the same field;

7. That it is debatable whether one man should receive credit for the final result he obtains after a long series of studies has been carried out by others before him;

8. That the policy of obtaining patents will lead to ill feeling and personal jealousies among investigators; and

9. That the act of securing patents is in itself evidence that he (the scientific investigator) desires financial profits from his work. ${ }^{9}$

After analyzing these objections and seeking answers to them in the literature and in the personal experiences of the members of the committee and other interested scientists, the committee reached the conclusion that the patenting of the

\footnotetext{
${ }^{7}$ Henderson, Patents Are Ethical, 77 Scrence 324-325 (March 1933).

${ }^{8}$ Sevringhaus, Should Scientific Discoveries Be Patented?, 76 Scrence 233 (Scpt. I932).

- The Protection by Patents of Scientific Discoveries, Report of the Committec on Patents, Copyrights and Trademarks, American Association for the Advancement of Science 8-r3 (1934).
} 
results of research which have some commercial importance or industrial application is highly desirable:

Our patent laws have been enacted in accordance with the provision in the Constitution, "to promote the progress of science and useful arts, by securing for limited times to authors and inventors the exclusive right to their respective writings and discoveries."

The investigator who takes advantage of our patent laws is therefore perfectly warranted in his act not only for any possible financial returns but also for the good of the public. The obtaining of some remuneration from a patent is no more debasing or tainted with commercialism than the acceptance of copyright royalties from a textbook or even receiving a salary for teaching. We are at present living in an economic structure in which the making of legitimate profit is a fundamental assumption.

The recent economic crisis has reduced the funds available for research to an alarming extent. Scientists are therefore warranted in legitimately obtaining funds from the results of their own work whenever they can do so by patents. In this way they will be able to finance their own work, extend their researches, and at the same time make contributions both to science and industry. ${ }^{10}$

In its report the committee also pointed out definite advantages in securing patents on important scientific discoveries, since only by means of patents can the legal right be secured to exclude others from practicing a given process or commercializing a new product:

By having such control of new discoveries the investigator is assured that his results will be used only for proper and meritorious purposes. He can prevent the exploitation of the public by dictating the terms under which his patent should be worked and even control the character of the commercial advertising. ${ }^{11}$

\section{II}

Interest in science and scientific research, particularly in the physical and natural sciences, has been intensified and accelerated as a result of our experiences during the war. Research workers and scientific investigators from the university campus and industrial laboratory aided materially in the magnificent record our nation made in war production and military achievement. Returning now to the campus and the laboratory, on release from wartime responsibilities and occupations, they are more research-minded than ever. Interest in research is being further stimulated by government and industry, which are turning to universities and technological institutes for assistance in solving postwar problems.

American science faces a challenging future. Can science be mobilized for peacetime purposes as effectively as for war? Will scientific investigation be conducted under conditions favorable to the search for new knowledge? Can we build upon and utilize our wartime experiences and the present research-consciousness among scientists and the public generally? How will our universities, the primary source of independent scientific investigation, respond to the challenge? These are ques-

${ }^{10} \mathrm{Id}$. at 14 .

11 Ibid. 
tions of paramount importance if this nation is to discharge its responsibilities and assume leadership for peace and progress in the postwar era.

Of direct concern to university administrators and scientists engaged in the formulation and conduct of research programs is the policy or procedure to be followed in handling the results of scientific investigation. How can the greatest public benefit be obtained from new discoveries and inventions? Specifically, how should these discoveries and irventions be administered in the public interest, taking into account the objectives of the institutions and the over-all welfare of the scientific workers?

Whether we are to enter upon a rich era of productive research, building upon and utilizing our wartime experiences and the present research-consciousness among scientists and the public generally, will depend to a large extent upon the philosophy behind our university programs and the administration of those programs. The public welfare, educational objectives, direction of scientific thought, and advancement of knowledge are all involved.

As a service to American higher education and to the scientific fraternity, the National Research Council has been making a comprehensive study of this problem. As a first step, a factual survey ${ }^{12}$ is being made of the prevailing policies, procedures, and practices in educational institutions and nonprofit organizations for the administration of patentable results of scientific research, with a view to the early publication of the findings for the information and guidance of all concerned. Through correspondence, conversations, and visits to university and other research centers all available information is being assembled concerning existing practices and present thinking, in administrative and scientific circles, about research policies and patent management programs.

At present there is a wide diversity of practice among educational institutions -and even at the same institution-in dealing with patentable discoveries and inventions growing out of scientific research. There is no common pattern of policy statement, administrative procedure, recognition of inventor, determination of equities, assignment requirement, patent management plan, distribution of proceeds, or protection of the public interest. Nor is there any convenient grouping according to type or size of institution, complexity of university organization, or kinds of research undertaken. Existing practices vary from strictly drawn patent policies to laissez faire attitudes and even an unwillingness to become concerned with the problem.

Some institutions follow a hands-off policy, leaving to the individual inventor the responsibility for determing what disposition is to be made of the product of his research efforts. Others take the position that the institution has an interest in all research activity on the campus and have established formal patent policies or follow generally accepted practices for handling any patentable discoveries that

12 Palmer, University Patent Policies, 33 Assoctation of American Colinges Bulletin r67-174 (March 1947). 
may result. Still others observe a definite policy of not having a patent policy. However, a great many have given little or no consideration to the patent problem, despite the increasing volume of scientific investigation on the campus.

Through the years certain institutions, faced with immediate situations, have formulated more or less definitive patent policies. Yet less than forty institutions have formally adopted such policies thus far, more than half of them during the past five years. At a number of other institutions practices and procedures are being currently followed which, though not definitely formalized, are generally accepted as applicable to research activities throughout the institution. A few have adopted special policies or recognize general practices for dealing with those results of scientific investigation that affect public or private health. Others have developed policies and practices only with respect to sponsored research.

Many of the existing policies and most of the prevailing practices are currently under review to meet changing postwar conditions and current considerations in the institutions. The need at this time for critical examination of the whole question of what to do with the patentable products of research, and also of its relation to scientific research programs and the over-all policies of the institutions, is recognized by those concerned with these programs and with the general administration of the institutions. Faculty and trustee committees are currently studying the question at a number of institutions, many of which have not previously had any patent policy, with a view to formulating new policies or revising existing ones.

\section{III}

At a number of institutions each case is decided on its individual merits in accordance with a general policy or, in the absence of such a policy, by agreement among the parties concerned. A few still feel that they discharge their responsibility by merely publishing the results of investigations or by securing patents and dedicating them to the public. Others accept full responsibility for obtaining patents and administering the patent rights in the public interest. Many exercise control over the patents by issuing licenses and accepting royalty payments, either directly or through a designated patent management agent.

Some recognize the rights and interests of the inventor and share the proceeds with him, either under a prior contractual arrangement or by mutual agreement. There is no uniformity in the division of the financial return from patents between the inventor and the institution. In some institutions the amount given the inventor is specified in accordance with a general policy, with a wide variation among institutions in the proportion allotted to the inventor. In others the inventor's share is determined in each case after consideration by a special faculty or administrative committee. A few institutions include patent provisions in their contracts of employment, in some instances for all faculty members but more often limited to members of the staff whose entire or major responsibility is research, especially contractual research. 
At most institutions the compulsory assignment of patent rights is not considered desirable, except in connection with cooperative or sponsored research. Voluntary assignment is preferred and in many institutions is encouraged and facilitated either through procedures and special machinery for handling patents set up within the institution or through the services of an outside organization closely related to the institution or under contract as its patent management agent.

Some institutions administer patent applications and the resulting patents directly, utilizing their regular administrative personnel or special units, either within the institutions or separately organized but responsible to their boards of trustees. Others, for legal or fiscal reasons, use the facilities of separately incorporated patent management foundations, independent of but closely allied to them. Still others have entered into agreements with Research Corporation, a non-profit patent management foundation, to handle patentable discoveries in their behalf. Most institutions endeavor to avoid becoming involved in the intricate legal and commercial aspects of patent management, mainly because they lack personnel with the requisite specialized knowledge and experience.

Nearly all the formalized patent policies and many of the generally accepted practices cover all types of research on the campus. Most of the others are concerned mainly with problems growing out of sponsored research projects supported by outside agencies on a contract basis. Certain institutions are unwilling and a few refuse to undertake research projects which entail patentable developments. Others are willing to undertake such projects only when they retain complete control over both the patent rights and the publication of the results of the investigation. Still others will enter into contracts under which the sponsor receives, for a consideration, ownership of all patentable discoveries, as well as full and confidential reports on the research findings.

There is no uniformity in the terms or conditions under which sponsored research is accepted and conducted, nor in the determination of charges. Some institutions have established specific policies for handling such research; others make the best arrangements obtainable in each case. Some will accept only projects which are definitely related to their educational programs and which can be performed by faculty members and students as part of their regular activities. Others have set up special facilities for sponsored research, employing personnel who devote full time to such activities. A number have established special research bureaus or divisions within the institution to relieve the faculty and regular administrative personnel from contractual relations with research sponsors.

It is the usual practice for educational institutions to retain control over the publication of the results of research conducted on the campus. When an investigation is financed through outside funds, that control is frequently but not always exercised subject to prior consent of the sponsor and after a reasonable time, to protect patent applications and the interests of the sponsor in commercial development. A few 
institutions which turn over all the results to the sponsor, including publication privileges as well as patent rights, merely reserve approval of any reference to the institution or its part in the investigation. In some instances they proscribe use of the name of the institution in any way.

\section{IV}

In order to encourage personal research interests of faculty members and other employees, most educational institutions place little or no restriction on the disposition of inventions and patentable discoveries resulting from scientific research conducted on an individual's own time and at his own expense, even when the institution's facilities and equipment are used. Such inventions are considered to be the exclusive property of the inventor and he retains the full patent rights and complete freedom to dispose of them as he deems proper.

It is the general practice at a number of institutions, particularly smaller colleges, which have had little or no experience with the problem and no urgent occasion as yet to adopt formal patent policies, to allow their faculty personnel the widest freedom in these matters. When the issue has arisen, it has either been decided by mutual agreement or the college has disclaimed any share in royalties or other benefits. Faculty committees and administrative officers have usually ruled in favor of the inventor when any question has been raised as to the institution's having any interest or equity in the discovery.

Institutions with formalized patent policies usually recognize, by explicit reference or by implication in formal policy statements, that an invention or discovery which is not related to the individual's regular teaching or research responsibilities belongs to the inventor, and accordingly waive all claim to a share in possible financial returns. Similarly, at many of the institutions which, in the absence of an established policy, follow generally accepted practices, as well as those which observe a laissez faire or hands-off policy, ownership of patents resulting from personal research rests with the inventor. This is also one of the basic considerations in most of the new policies now being formulated.

At a few institutions a distinction is made between discoveries within the inventor's field of employment and those outside that field. Almost invariably those employed for full-time research in state agricultural and engineering experiment stations and in the special research institutes affiliated with educational institutions are required to sign patent assignment agreements covering all patentable inventions in any way related to their work.

In the absence of established policies some institutions consider each case on its merits, leaving it to the judgment of the faculty member whether he should bring the matter to the attention of the president or designated administrative officer or faculty committee charged with consideration of research and patent problems. A few universities with definite patent policies require that all patentable discoveries, 
as well as the intention to apply for patents, be brought to the attention of the administration, either directly or through appropriate committees.

In the administration of formal patent policies a number of institutions have established committees on patents to advise and aid faculty members on matters of patentability, prosecution of the patent application, commercialization of the patent when issued, and general business aspects of patent management. Through these committees and the regular university administrative organizations, and also through the facilities of affliated patent management foundations where they exist, means are provided whereby, by voluntary assignment of their patent rights, faculty members may be relieved of the burdensome legal and administrative problems associated with the commercial exploitation of patents.

Frequently these committees also have responsibility for determining whether the institution has any interest or equity in the discovery and for defining what action should be taken in line with the prevailing patent policy or accepted practice of the institution. In many instances it is difficult to determine the extent to which incidental or permitted use of equipment and other facilities, membership in the company of scholars assembled on the campus, professional contacts with colleagues and others connected with the institution, and the general atmosphere and surroundings contribute to the evolution of patentable ideas. Certain institutions require reimbursement of whatever contribution in institutional time, money or facilities has been made to the production of a patentable discovery, even though the patent rights remain the sole property of the inventor.

Few patent policies include any reference to patentable discoveries resulting from student research, except where the student is employed or receives specific fellowship aid under an industrial research contract. In general, inventions made by students, including those on academic scholarships and fellowships, are considered to be the private property of the students. The question of requiring students to sign patent assignment agreements is occasionally raised, especially when scholarship aid is involved. In a patent policy recommended some years ago for a midwestern university, research fellows were treated as intermediate between faculty members and students, and it was proposed that any inventions made by a research fellow under any circumstances should be the property of the university. ${ }^{13}$ In cases where the student is receiving scholarship aid, the acceptance of such aid is generally not considered as changing the status of the student in regard to title to inventions or developments, since such scholarship funds are provided primarily for the assistance of outstanding students and are in general administered by, rather than controlled by, the institution. The rights of the student include the right to assign or otherwise dispose of his patent rights.

Even where inventions and other developments grow out of research which is entirely or substantially financed by the institution there is considerable variation

${ }^{18}$ Richard Spencer, University Patent Policies Io (1939). 
in the patent policy observed, the procedures followed, and the recognition of the inventor. However, it is generally the practice to require assignment of title to such inventions and developments, as well as any patent rights that may accrue from them, to the institution or to its designated agent when the research is part of the regular duties and responsibilities of a faculty or staff member. In such cases the institution bears the costs of obtaining the patent and assumes responsibility for its exploitation. Provision is usually made for the patent rights to revert to the inventor if the institution or its designated agent does not file a patent claim within a reasonable time, which is sometimes but not always specified in the assignment agreement.

Exceptions to the general rule are found, for the most part, in those institutions which observe a definite hands-off patent policy and leave all such matters to the discretion of the inventor. In certain of these institutions, however, restrictions are placed on discoveries affecting public or individual health. A few institutions make a distinction between discoveries within the inventor's field of employment and those outside that field, as in the case of personal research conducted on the individual's own time and at his own expense.

Most institutions require full-time research personnel and others employed on special research projects to sign patent assignment agreements covering all patentable ideas and discoveries that may result from their investigations. Such agreements are generally required of full-time research employees in state agricultural and engineering experiment stations, and also of those employed on projects conducted in or under special research institutes affiliated with educational institutions.

A number of institutions have special committees or boards to which are referred patentable discoveries and questions of the institution's interest in them and the desirability of securing patents at the institution's expense. These committees usually also determine what recognition or reward, if any, should be given to the inventor when recommending the specific action to be taken in each case. In many instances the inventor is required or advised to assign his rights to a patent management organization designated by the institution to represent its interest and handle the commercialization and general administration of the patent rights.

\section{$\mathrm{V}$}

The war effort lent strong impetus to the long-term expansion of total research and development expenditures in the United States. In the five years from I94I to r945 three billion dollars was spent for these purposes, almost all of it going for developmental work on implements of war, with about 83 per cent of the total cost being financed by the Federal Government. Despite these vast expenditures during the war, the Nation's postwar budget for research and development during 1947 will reach the highest point in our history-more than a billion dollars. ${ }^{14}$

Both government and industry have been making increasing demands upon the

\footnotetext{
is Science and Public Policy, Report of the President's Scientific Research Board (r947).
} 
personnel and facilities of the universities and technological institutes for assistance in their postwar programs. As a result university research has been receiving added stimulus from these outside sources. The situation, particularly in industrial laboratories, is made more acute by the critical shortage of scientific and technical personnel and difficulties in obtaining construction material and laboratory equipment.

The Federal Government, cognizant of the magnitude of the problem and its relation to the national defense and the public welfare, is launched upon an extensive program and is spending a considerable portion of its research and development budget in the colleges and universities. Industry is also looking to the colleges and universities for assistance in solving its reconversion problems. Unable to provide within their own resources means for producing new ideas for the improvement and replacement of obsolete facilities and processes to meet postwar conditions, large and small businesses alike, as well as trade associations and groups of related industrial firms, are seeking the services of educational institutions in research work on specific developmental problems.

Despite the heavy teaching load resulting from swollen postwar enrollment and their lack of adequate instructional stafts, educational institutions in all parts of the country have been quick to respond to this new call. A number of these institutions have for years been rendering such service to industry, both on an institutional basis and through consulting and research work on the part of individual staff members. This has been particularly true in state universities, land-grant colleges and technological institutes. However, largely as the result of experiences with war contracts and observation of what others have done and are doing, there has been a material increase during the past several years in the number of colleges and universities offering research services to industry.

An appendix in the National Research Council's recently published directory of industrial research laboratories ${ }^{15}$ lists approximately three hundred educational institutions which offer such services, and the list is admittedly incomplete. At a number of institutions special research institutes, corporations, and foundations, both independently incorporated and with institutional affiliation, have been established for the conduct and administration of sponsored research programs, as well as for the management of the patentable results of research.

Encouraged by the success, often more apparent than real, of certain of these organizations, more than seventy colleges, universities, and technological institutes have set up agencies, many within the past three years, and others are contemplating similar action. These organizations are located in all parts of the country and at all types of institutions, large and small, public and private-at endowed universities, state universities, land-grant colleges, technological institutes and small colleges alike.

Some are integral parts of the administrative and organic structure of the insti-

${ }^{25}$ Indutstrial Research Laboratories in the United States 349-355 (8th ed. 1946). 
tutions concerned, usually as special research departments or divisions. Others are independent non-profit foundations, separately incorporated but closely affiliated with the educational institutions and utilizing their personnel and facilities. A few maintain special research laboratories and separate personnel who are distinct from the regular teaching staffs of the institutions. Combinations of full-time services of special research workers and part-time research and supervisory services of regular teaching members are found at a number of institutions.

Many of these agencies have been set up to provide convenient means for relieving the institution's regular business and administrative staff of contractual relations with research sponsors and of patent management problems. In some instances they are also concerned with the general development of new sources of financial support for the institution itself. Still others are designed to provide machinery for conducting sponsored research activities, particularly where restrictive statutory provisions make it either impossible or undesirable for the institutions to perform these services themselves. In tax-supported institutions these agencies provide media for keeping the supplemental revenue from sponsored research and patents outside the regular fiscal controls of the institution.

There is a wide diversity in the organization and operation of these agencies and in their handling of the policies and responsibilities of sponsored research programs. As has been previously observed, there is no uniformity in the terms or conditions under which these sponsored research projects are accepted and conducted, nor in the determination of the charges made. The patentable products of such research are handled in many different ways, the ownership and control of patent rights sometimes being retained by the university but more often being turned over to the sponsor under a predetermined contractual arrangement.

\section{VI}

An important-and controversial-aspect of the patent problem is concerned with the patentable products of scientific research that affect public and individual health, particularly discoveries and inventions of a medical, pharmaceutical, therapeutic, or hygienic nature. Those universities that have comprehensive patent policies usually include such discoveries, processes, developments, and inventions within the scope of general over-all policies. A few provide specifically for a different treatment of medical discoveries, designed to discourage patenting except when it is considered necessary in the public interest and then without consideration of profit, either to the individual or to the institution. A considerable number have no fixed policy: when cases arise, each one is handled individually, usually without any uniform pattern except, as a general rule, to discourage investigators from seeking patents.

The prevailing practices of educational institutions, especially those with medical faculties, are influenced to a considerable extent by the traditional attitude of the medical profession as to the ethics of patenting medicinals and medical appliances 
and by failure to differentiate between patenting for personal gain and patenting in the public interest. Many scientists working in this field also take the position that the results of their research, both patentable and otherwise, should be shared "without fee or stipulation." Such an attitude, however, does not preclude patenting a new process or discovery in the public interest.

Through the centuries medicine has given freely of its discoveries for the benefit of mankind and these discoveries have become the property of all who cared to employ them in the control of disease. However, as medicine has become more complex, involving specialized investigations in the fields of biochemistry, physiology, physics, and associated branches, great numbers of full-time research scientists in the hospital and the laboratory work with members of the medical profession but are not bound by the same ethical principles. Many important medical preparations and techniques have been developed in university laboratories, often at considerable expense to the institutions.

In order to obtain a comprehensive picture of the present situation in educational institutions with regard to the handling of patents in this field, a special study has been made of the practices of the sixty-nine medicals schools on the approved list of the Council on Medical Education and Hospitals of the American Medical Association and of the universities and colleges with which fifty-nine of them are affiliated. It was found that:

Eight of the university-affliated medical schools have special policies for dealing with medical patents, several of which are applicable on a university-wide basis.

Nine others conform to formalized general university policies for handling all types of patentable results of scientific research.

The other forty-two have no formal or established policy, either in the medical school or in the university at large, although many of the medical schools follow practices which are generally accepted throughout the universities with which they are affiliated.

Only two of the ten independent medical colleges have clearly defined policies; the other eight 'either follow informal policies or have no policy at all.

The patent question is currently under review at more than half of these medical schools, at a number of them as part of new or revised general university policies. Obviously the patent problem is not a settled one in the medical schools, and a wide difference of opinion exists among their faculty members as to the ethics of patenting a medical discovery; but, in those schools, as in educational institutions generally, the question is being given thoughtful consideration at the present time. Much of the stimulation for the establishment of definitive patent policies stems from problems growing out of research projects sponsored by outside agencies, especially commercial firms. Frequently such practices as are currently followed are concerned solely or mainly with the results of scientific research conducted under grants from these outside sponsors.

\footnotetext{
${ }^{10}$ As part of the patent policy, survey now being made by the National Research Council, to be published early in 1948 .
} 
The complexity of the problem and the wide variation of procedure in handling medical discoveries are clearly indicated in the prevailing practices of these fiftynine approved university medical schools and ten independent medical colleges. The view has been expressed by some scientific investigators that no patents should be taken out for discoveries or inventions in the medical field which may affect individual or public health, and that the control should be left to legislative action. Nevertheless, patenting such discoveries is not considered to be wrong in itself, but to be desirable to control them in the public interest.

\section{VII}

Patent management is a complicated business and is expensive. It requires a high degree of legal competence, administrative astuteness, and promotional zeala combination of talent not always readily available in an educational institution. The patent search is a specialized technical job. The preparation and processing of patent applications is exacting work for legal counsel. The administration of patent rights demands careful attention to intricate details and constant watch for infringement. The exploitation and disposal of patents, through sale and licensing agreements, require salesmanship of a high order.

It is natural, therefore, that most educational institutions make every effort to avoid becoming directly involved in the intricate legal and commercial aspects of patent management. Some endeavor to accomplish this by adopting a hands-off policy and refusing to handle patents. Others utilize the facilities of separately incorporated patent management foundations, independent of but in some instances closely related to the institution by the terms of their charters and by the membership of trustees, administrative officers, and faculty on their boards of directors.

A few attempt to handle patents as a part of the routine duties of already established administrative units, such as the comptroller's or business office, or through especially designated committees responsible directly to the administration or to the trustees. A number have faculty committees on patents which exist primarily for the purpose of insuring that pertinent institutional regulations are observed; or they may be advisory bodies charged with recommending action on matters that range from the desirability of taking out a patent to the determination of equities.

There are at least three distinct equities or interests involved in patentable discoveries or inventions resulting from scientific research in an educational institution: (x) the inventor or inventors; (2) the institution, and (3) the general public, to which must be added a fourth, the sponsor or supporter of the research, in the case of sponsored research. When further developmental work is necessary, a fifth interest may be involved, although frequently the developer is the same as the sponsor or supporter of the original research. 
The recognition and protection of these several and diverse interests naturally complicates any individual situation. Self-interest, personal rights, institutional policies, employer-employee relations, academic freedom, contractual relations; patent law, business practices, commercial competition, and the variables in individual cases are some of the elements that contribute to the problem. Nevertheless, to be equitable and effective a patent policy must provide for such recognition and protection, placing the responsibility where it can be discharged most expeditiously and with the minimum of burden on the regular administrative and teaching staffs of the educational institution. 